\title{
ИСПОЛЬЗОВАНИЕ СПЕЦИАЛЬНЫХ ЗНАНИЙ ПРИ РАССЛЕДОВАНИЯХ ТЕРРОРИСТИЧЕСКИХ АКТОВ
}

\author{
Н.Б. Мергембаева \\ Евразийский национальньй университет им. Л.Н. Гумилева, \\ Нур-Султан, Казахстан, \\ e-mail:nurgul2407@mail.ru
}

Рассматривается комплекс проблем судебной экспертизы при расследовании преступлений против общественной безопасности и общественного порядка на основе анализа уголовных дел.

Ключевые слова: судебная экспертиза, институт специальных знаний, заключение эксперта.

\section{USE OF SPECIAL KNOWLEDGE IN THE INVESTIGATION OF TERRORIST ACTS}

\section{N.B. Mergembaeva \\ Eurasian National University. L.N. Gumilyov, Nur-Sultan, Kazakhstan, e-mail:nurgul2407@mail.ru}

The study of the complex problems of judicial expertise in investigating crimes against public safety and public order based on the analysis of criminal cases.

Key words: forensic examination, institute of special knowledge, expert opinion.

DOI 10.14258/ssi(2019)3-6281

\section{Введение}

В настоящее время проблема терроризма является наиболее актуальной в связи с ростом количества террористических атак, совершаемых различными террористическими организациями по всему миру. Постоянная угроза террора приводит к дестабилизации политической, экономической, социальной обстановки в государстве. Данная проблема коснулась нашего государства в 2011 году: тогда в Республике Казахстан прогремел ряд террористических актов, в частности на западе страны. В связи с этими событиями в Казахстане выработалась и постепенно совершенствуется система мер обеспечения безопасности общества и государства от террористических угроз, что позволило накопить определенный опыт в выявлении и пресечении деятельности террористических организаций. В последние годы в нашей стране проделана значительная работа по созданию и совершенствованию законодатель- 
ной и организационной базы для выявления и пресечения предпосылок терроризма и экстремизма. В июле 1999 г. в Казахстане был принят Закон «О борьбе с терроризмом», определивший правовые и организационные основы борьбы с терроризмом в республике, порядок деятельности государственных органов и организаций, независимо от форм собственности, а также права, обязанности и гарантии граждан в связи с осуществлением борьбы с терроризмом. Одним из главных направлений борьбы с терроризмом является деятельность по расследованию террористических актов. Как правило, расследование террористических актов в силу особенностей данного вида преступлений имеет определенную специфику, она касается использования специальных знаний при расследовании данного вида преступлений. По террористическим актам наиболее часто назначаются следующие виды экспертиз:

- судебная взрывотехническая экспертиза;

- судебная пожарно-техническая экспертиза;

• судебная баллистическая экспертиза;

- судебно-медицинская экспертиза;

• судебная трасологическая экспертиза.

\section{Результаты и обсуждение}

Каждая из перечисленных экспертиз при расследовании террористических актов имеет свою специфику. Так, судебная взрывотехническая экспертиза решает многие вопросы, стоящие перед следствием и судом. Практика расследования преступлений, совершенных с применением взрывных устройств (далее - ВУ), показывает, что данная экспертиза назначается во всех случаях. Реже назначаются дактилоскопическая, трасологическая, пожарно-техническая, автотехническая и т.д.

Преступники все чаще и чаще избирают в качестве орудия совершения преступлений взрывные устройства. Это объясняется тем, что взрыв, обладая мощной разрушающей силой, способен поразить жертву на значительном расстоянии, может быть запрограммирован на определенное время либо инициирован какими-либо действиями жертвы или радиосигналом. Для совершения криминальных взрывов преступники используют взрывные устройства, основными элементами которых являются заряд взрывчатого вещества и конструктивно соединенное с ним средство инициирования, размещенные в корпусе или иной оболочке. Взрывы стали использоваться также с целью сокрытия других преступлений. После взрыва на месте происшествия остается минимальное количество следов как от самого преступника, так и от использованного им взрывного устройства. Избрание взрывного устройства в качестве орудия совершения преступлений обусловлено относительной несложностью его приобретения либо изготовления (проведенный автором анализ судебно-следственной практики показывает, что 48\% от общего объема исследуемых объектов взрывотехнической экспертизы составляют самодельные взрывные устройства). Связано это прежде всего с тем, что изготовить самодельное взрывное устройство возможно способами, полученными из общедоступной сети Интернет, даже не обладая при этом специальными познаниями в области взрывотехники. Однако, как показывает практика, из-за малоуправляемой энергии взрыва, а в некото- 
рых случаях из-за неопытности исполнителей преступные замыслы не всегда достигают желаемого результата (физического устранения конкретных лиц), но всегда влекут за собой тяжкие последствия в виде гибели случайных жертв, уничтожения или повреждения зданий, имущества и материальных ценностей.

Для исследования ВУ, которые нередко становятся орудием совершения террористических актов, назначается судебная взрывотехническая экспертиза. В ходе производства взрывотехнической экспертизы решаются сложные задачи, к которым прежде всего относятся: установление самого факта взрыва, выявление природы и механизма взрыва, определение эпицентра взрыва, установление конструкции ВУ и принцип его действия, определение массы использованного заряда взрывчатого вещества и его поражающих свойств, установление происхождения: является ли взрывное устройство самодельным либо промышленного изготовления. Данный перечень вопросов не является исчерпывающим, могут возникать и другие - в зависимости от конкретных ситуаций.

Следует отметить, что в настоящее время процент раскрываемости преступлений рассматриваемой категории остается достаточно низким. Несмотря на принимаемые государством усилия, направленные на совершенствование мер по пресечению, раскрытию и расследованию преступлений, совершенных с применением взрывных устройств, правоохранительные органы нуждаются в наличии не только специальных технических средств борьбы с ними, но и в навыках и умениях следственной, оперативно-разыскной и экспертной работы, а также в специально разработанной в криминалистической науке методике расследования криминальных взрывов, подкрепленной новейшими ее достижениями.

В связи с многообразием объектов исследования взрывотехническая экспертиза носит комплексный характер, для чего кроме экспертов-взрывотехников привлекаются специалисты других областей знаний. Например, необходимо установить, имеются ли на представленных предметах остатки (микрочастицы) взрывчатого вещества и какого именно. Данная экспертиза проводится в комплексе с судебной экспертизой веществ и материалов.

Нередко возникает необходимость назначения других экспертиз, с целью решения специфических задач. К их числу относятся как традиционные криминалистические, так и иные экспертизы. К примеру, судебно-медицинская экспертиза согласно ст. 271 Уголовно-процессуального кодекса РК назначается в обязательном порядке, если необходимо установить причину смерти, характер и степень тяжести причиненного вреда здоровью. Судебно-медицинские эксперты дают заключения по вопросам медицинского, а также биологического характера, связанным с жизнедеятельностью и функциями человеческого организма. Типичные вопросы, разрешаемые судебно-медицинской экспертизой при взрывах: причинены ли обнаруженные на теле повреждения взрывом, каково было расстояние от взрывного устройства до потерпевшего, определение позы потерпевшего в момент причинения ему повреждения, соответствуют ли повреждения на теле потерпевшего повреждениям на его одежде, имелась ли преграда между потерпевшим и взрывным устройством в момент взрыва и т.п. 
Судебная экспертиза психофизиологических процессов человека также имеет большое значение при расследовании террористических актов. Это связано с психическими особенностями лиц, совершивших преступление террористического характера. Она способствует объективному установлению субъективной стороны преступления.

\section{Заключение}

Экспертное исследование должно быть объективным, т.е. базироваться на строго научной основе и осуществляться в пределах соответствующей специальности в полном объеме, необходимом для установления обстоятельств по конкретному делу. В последние годы для разрешения вопросов, стоящих перед расследованием, требуются специальные знания не только в области криминалистики, но и в других областях, и в связи с этим наблюдается тенденция к комплексности экспертных исследований. В современной экспертизе наблюдается переход от изолированных исследований, ограниченных применением данных одной отрасли науки или техники, к исследованиям комплексным, в которых используются данные различных наук.

С помощью судебно-психологической экспертизы открывается возможность выявления мотивации террористов. Обоснована целесообразность назначения посмертной судебно-психологической (судебной психолого-психиатрической) экспертизы в отношении террористок-смертниц, а также в случае посткриминального суицида террористов в период проведения досудебного расследования.

В данный период в отечественной специальной литературе отсутствуют рекомендации по назначению судебных экспертиз, направленных на изучение психического состояния террористов. Судебно-следственная практика свидетельствует о необходимости назначения судебно-психиатрической, судебно-психологической и психолого-психиатрической экспертизы по делам о преступлениях террористического характера.

Таким образом, судебная экспертиза является опосредованным средством доказывания, проводимым специальным субъектом с целью получения фактов, которые могут быть установлены только с помощью экспертного исследования, результаты этого исследования оформляются специальным документом - заключением эксперта.

\section{БИБЛИОГРАФИЧЕСКИЙ СПИСОК}

О противодействии терроризму: Закон Республики Казахстан от 13 июля 1999 г. № 416-I.

О судебно-экспертной деятельности Закон Республики Казахстан от 10 февраля 2017 г. № 44-VI.

Уголовно-процессуальный кодекс Республики Казахстан от 4 июля 2014 года № 231-V.

Перечень видов судебных экспертиз, проводимых органами судебной экспертизы, и экспертных специальностей, квалификация по которым присваивается Министер- 
ством юстиции Республики Казахстан, утвержденный Приказом Министра юстиции Республики Казахстан от 27 марта 2017 г. № 306.

Шакиров К.Н. Судебная экспертиза. Проблемы теории и практики. Алматы: Аркаим, 2002.

Саханова Т.В. Судебная экспертиза. М., 2000.

\section{REFERENCES}

O protivodejstvii terrorizmu: Zakon Respubliki Kazahstan ot 13 iyulya 1999 g. № 416-I [On Countering Terrorism: the Law of the Republic of Kazakhstan of July 13, 1999 No. 416-I].

O sudebno-ekspertnoj deyatel'nosti: Zakon Respubliki Kazahstan ot 10 fevralya 2017 g. № 44-VI [On Forensic Expertise: the Law of the Republic of Kazakhstan dated February 10, 2017 No. 44-VI].

Ugolovno-processual'nyj kodeks Respubliki Kazahstan ot 4 iyulya 2014 goda № 231-V [Criminal Procedure Code of the Republic of Kazakhstan dated July 4, 2014 No. 231-V].

Perechen'vidov sudebnyh ekspertiz, provodimyh organami sudebnoj ekspertizy, i ekspertnyh special'nostej, kvalifikaciya po kotorym prisvaivaetsya Ministerstvom yusticii Respubliki Kazahstan, utverzhdennyj Prikazom Ministra yusticii Respubliki Kazahstan ot 27 marta 2017 g. № 306 [The list of types of forensic examinations conducted by the bodies of judicial expertise and expert specialties, qualifications for which are assigned by the Ministry of Justice of the Republic of Kazakhstan, approved by order of the Minister of Justice of the Republic of Kazakhstan dated March 27, 2017 No. 306].

Shakirov, K.N. (2002). Sudebnaya ekspertiza. Problemy teorii i praktiki [Forensic examination. Problems of theory and practice]. Almaty: Arkaim.

Sakhanova, T.V.(2000). Sudebnaya ekspertiza [Forensic examination]. M. 2000. 